\title{
A Quantitative Survey of Gravity Receptor Function in Mutant Mouse Strains
}

\author{
Sherri M. Jones, ${ }^{1}$ Kenneth R. Johnson, ${ }^{2}$ Heping Yu, ${ }^{2}$ Lawrence C. Erway, ${ }^{3}$ Kumar N. Alagramam, ${ }^{4}$ \\ Natasha Pollak, ${ }^{5}$ and Timothy A. Jones ${ }^{1}$ \\ ${ }^{1}$ Department of Communication Sciences and Disorders, East Carolina University, Greenville, NC 27858, USA \\ ${ }^{2}$ The Jackson Laboratory, Bar Harbor, ME 04609, USA \\ ${ }^{3}$ Department of Biological Sciences, University of Cincinnati, Cincinnati, OH 45221, USA \\ ${ }^{4}$ Department of Otolaryngology-Head and Neck Surgery, University Hospitals of Cleveland, Case Western Reserve University, \\ Cleveland, $\mathrm{OH}$ 44106, USA \\ ${ }^{5}$ Department of Otolaryngology, University of Missouri School of Medicine, Columbia, MO 65212, USA
}

Received: 4 October 2004; Accepted: 20 June 2005; Online publication: 19 October 2005

\begin{abstract}
The purpose of this research was to identify vestibular deficits in mice using linear vestibular evoked potentials (VsEPs). VsEP thresholds, peak latencies, and peak amplitudes from 24 strains with known genetic mutations and 6 inbred background strains were analyzed and descriptive statistics generated for each strain. Response parameters from mutant homozygotes were compared with heterozygote and/or background controls and all strain averages were contrasted to normative ranges. Homozygotes of the following recessive mutations had absent VsEPs at the ages tested: $E s p n^{j e}, A t p 2 b 2^{d f w-2 J}, \operatorname{Spnb} 4^{q v-l n d 2 J}, \operatorname{Spnb} 4^{q v-3 J}, M y o 7 a^{\text {sh1 }}$,

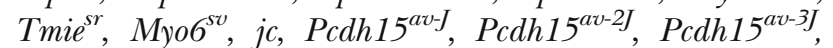
Cdh $23^{v-2 J}$, Sans ${ }^{j s}, h r, K c n e 1^{p k r}$, and Pou $3 f 4^{d e l}$. These results suggest profound gravity receptor deficits for these homozygotes, which is consistent with the structural deficits that have been documented for many of these strains. Homozygotes of Catna2 ${ }^{c d f}$, Grid2 ${ }^{h o 4 J}$, Wnt1 $1^{s w}$, $q k$, and $M b p^{s h i}$ strains and heterozygotes of Grid2 $2^{l c}$ had measurable VsEPs but one or more response parameters differed from the respective control group (heterozygote or background strain) or were outside normal ranges. For example,
\end{abstract}

Correspondence to: Sherri M. Jones · Department of Communication Sciences and Disorders, East Carolina University - Belk Annex, Greenville and Charles Boulevards, Greenville, NC 27858, USA. Telephone: (252) 328-4464; fax: (252) 328-4469; email: jonessh@ mail.ecu.edu $q k$ and $M b p^{s h i}$ homozygotes showed significantly prolonged latencies consistent with the abnormal myelin that has been described for these strains. Prolonged latencies may suggest deficits in neural conduction; elevated thresholds suggest reduced sensitivity, and reduced amplitudes may be suggestive for reduced neural synchrony. One mutation, $\operatorname{Otx} 1^{j v}$, had all VsEP response parameters within normal limits-an expected finding because the abnormality in $\operatorname{Otx}_{1} \mathrm{j}^{j v}$ is presumably restricted to the lateral semicircular canal. Interestingly, some heterozygote groups also showed abnormalities in one or more VsEP response parameters, suggesting that vestibular dysfunction, although less severe, may be present in some heterozygous animals.

Keywords: mutant mice, vestibular evoked potentials, genetic, otolithic function, electrophysiology, phenotype

\section{INTRODUCTION}

The inner ear houses sensory organs responsible for hearing and balance. The organ of Corti within the cochlea transduces sound, whereas the receptors within the maculae and ampullae transduce linear or angular motion (i.e., acceleration) of the head, respectively. Deficits in the inner ear organs or their neural innervation can lead to deafness, dizziness, or 
both. Factors that can affect inner ear structure and function include trauma, disease, drugs, aging, or genetic abnormalities. Studies of animal strains with genetic mutations have been instrumental in developing the scientific understanding of normal and abnormal inner ear development and continue to broaden this knowledge. The overall goal of our research program is to gain a better understanding of the role genes play in vestibular function.

Inner ear defects have been described for many mutant or inbred strains of animals including fish (e.g., Whitfield et al. 1996; Malicki et al. 1996; Riley and Grunwald 1996; Riley et al. 1997), birds (e.g., Ballarino and Howland 1986; Gleich et al. 1994a, b, 1995; Weisleder and Park 1994; Weisleder et al. 1996; Jones et al. 1998), and mammals (e.g., Ruben et al. 1991; Lyon et al. 1996; Zheng et al. 1999; Morton 2002; Steel et al. 2002). Among mammalian species, the mouse has a long history as a genetic model for hearing and/or balance dysfunction (e.g., Yerkes 1907; Lord and Gates 1929; Lyon 1953; Deol 1954; see also Ruben 1991; Henry and McGinn 1992; Steel and Brown 1994, 1996; Steel 1995; Lyon et al. 1996; Morton 2002; Parkinson and Brown 2002; Avraham 2003). Indeed, many mutant strains of mice have been identified with specific abnormalities of the cochlea and/or vestibular labyrinth (see Steel 1990, 1991, 1995; Lyon et al. 1996; Morton 2002; Steel et al. 2002; Avraham 2003).

Numerous studies have described the anatomical alterations that occur in both the cochlea and vestibular organs of genetic mutants. Investigations of the vestibular system in mutant mice have identified or further characterized structural deficits in otoconia (Lyon 1953; Lyon and Meredith 1969; Rauch 1979; Trune and Lim 1983b; Erway and Grider 1984; Rolfsen and Erway 1984; Bergstrom et al. 1998; Ornitz et al. 1997), hair cells (Deol 1954; Anniko et al. 1980; Dememes and Sans 1985; Wenngren and Anniko 1989; Sjostrom and Anniko 1990; Kitamura et al. 1991; Otani et al. 1995; Moriyama et al. 1997; Kozel et al. 1998), inner ear melanocytes (Cable et al. 1992, 1994), or vestibular nuclei (Trune and Lim 1983a; Krug et al. 1995; Grusser-Cornehls et al. 1995). In addition, many mutants used to document genetic cochlear deficits have cochleo-saccular degeneration (e.g., Steel and Bock 1983; Webster et al. 1986; Rask-Andersen et al. 1987; Lyon et al. 1996).

Functionally, cochlear deficits in mice can be documented using endolymphatic potentials, cochlear microphonic recordings, auditory evoked potentials (e.g., auditory brainstem response), otoacoustic emissions, and behavioral testing. In contrast, vestibular functional deficits in genetic mutants have been tested predominately with indirect measures such as observations of cage or swimming behavior as well as reflex behaviors during dropping or other motor tasks. Eye movement recordings, such as angular vestibuloocular reflex (aVOR) and optokinetic response (OKR), have also been used (e.g., Koekkoek et al. 1997; de Zeeuw et al. 1998; Kitazawa et al. 2000; van Alphen et al. 2001). The relative preservation of the OKR and complete absence of the aVOR may suggest a peripheral abnormality, specifically as it relates to the semicircular canal. However, eye movement recordings provide an indirect measure of peripheral vestibular dysfunction as they encompass the input, integration and output components of nervous system function. Furthermore, OKR and aVOR recordings do not provide sufficient information regarding the functional status of the receptors in the saccule and utricle.

Direct measures of peripheral vestibular function are available for use with animal models. For example, vestibular compound action potentials [also referred to as vestibular evoked potentials (VsEPs) ] have been recorded in several animal species (e.g., Elidan et al. 1987; Jones 1992; Bohmer 1995), including mice (Jones and Jones 1999; Jones et al. 1999, 2002, 2004). Such measures provide a direct assessment of and a unique perspective on the status of the vestibular periphery (end organs and eighth nerve).

The purpose of the present research was to quantitatively phenotype vestibular neural function (specifically gravity receptor function) in mutant mice using compound action potential recordings of the vestibular nerve (i.e., VsEPs to linear acceleration transients). Screening protocols were used to measure gravity receptor function in mice homozygous for several mutations and in age-matched heterozygotes or other control background strains. Response thresholds, peak latencies, and peak-topeak amplitudes were measured and compared to normative ranges and between homozygote and heterozygote or background strains where sufficient data were available for such a comparison. This research extends our understanding of vestibular ontogeny and vestibular dysfunction in relation to genetic mutations.

\section{METHODS}

Tables 1 and 2 list the background strains, mutant strains, ages, and number of mice tested per strain. The background strains tested were C57BL/6J (35, 90 , and 389 days old, $N=5$ per age), CBA/CaJ (166 days, $N=4$ ), DBA/2J (29 and 73 days, $N=5$ and 4 per age, respectively), C3H/HeSnJ (120 days, $N=5$ ), $\mathrm{BALB} / \mathrm{cByJ}$ (71 days, $N=4)$, and C3HeB/FeJ (64 days, $N=18$ ). Mice were obtained from The 


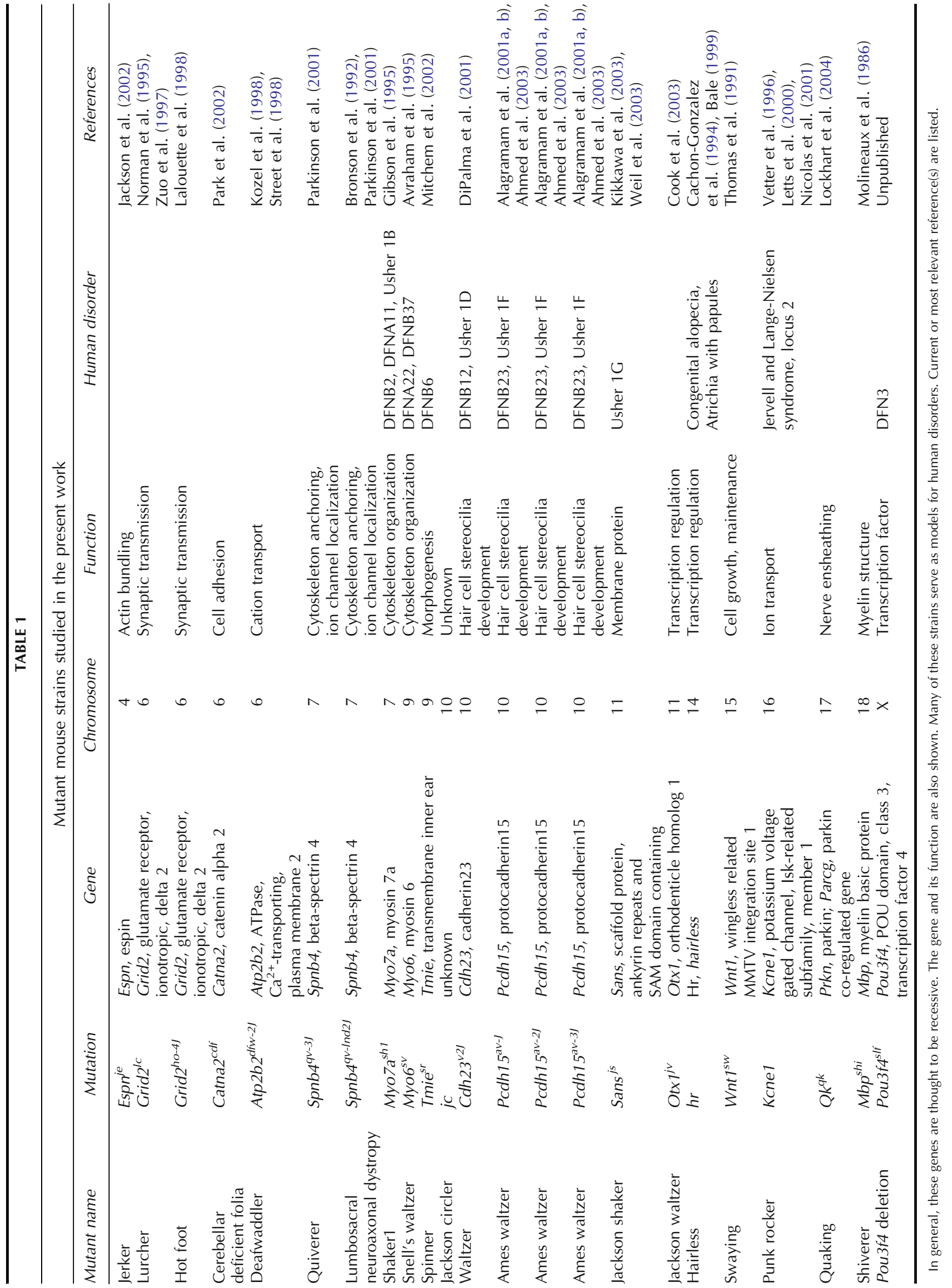


TABLE 2

Mutation, strain background, genotype, age (in days), and number of animals tested for each mutant and control genotype

\begin{tabular}{|c|c|c|c|c|c|c|c|}
\hline Mutation & Strain background & Mutant genotype & Age & Number & Control Genotype & Age & Number \\
\hline$E s p n^{j e}$ & JE/LeJ & je/je & 70 & 5 & $+/ j e$ & 39 & 4 \\
\hline Grid2 $^{/ C}$ & $\mathrm{C} 57 \mathrm{BL} / 6 \mathrm{~J} \times \mathrm{CBA} / \mathrm{CaJ}$ & & & & $+/ l_{C}$ & 45 & 5 \\
\hline Grid $2^{\text {ho-4J }}$ & $\mathrm{DBA} / 2 \mathrm{~J}$ & $h o^{4 J} / h o^{4 J}$ & 82 & 5 & & & \\
\hline Catna $2^{\text {cdf }}$ & $\mathrm{C} 3 \mathrm{H} / \mathrm{HeSnJ}$ & $c d f / c d f$ & 110 & 6 & $+/ c d f$ & 109 & 4 \\
\hline Atp $2 b 2^{d f w-2 J}$ & BALB/cByJ & $d f w^{2 J} / d f w^{2 J}$ & $28 ; 120$ & $3 ; 1$ & $+/ d f w^{2 J}$ & 120 & 3 \\
\hline$S p n b 4^{q v-3 j}$ & $\mathrm{C} 57 \mathrm{BL} / 6 \mathrm{~J}$ & $q v^{31} / q v^{3 j}$ & $45 ; 85$ & $2 ; 4$ & $+/ q v^{3 J}$ & 47 & 4 \\
\hline$S p n b 4^{q v-\operatorname{lnd} 2 J}$ & $\mathrm{C} 3 \mathrm{H} / \mathrm{HeJ}$ & $q v^{\ln d 2 J} / q v^{\ln d 2 J}$ & 25 & 5 & $+/ q v^{\operatorname{lnd} 2 J}$ & 35 & 4 \\
\hline Myo7a $a^{\text {sh1 }}$ & SH1/LeJ & sh1/sh1 & 26 & 4 & & & \\
\hline$M_{y o 6^{S V}}$ & $\mathrm{C} 57 \mathrm{BL} / 6 \mathrm{~J} \times \mathrm{STOCK}$ & $s v / s V$ & 52 & 4 & $+/ s v$ & 52 & 4 \\
\hline$T m i e^{s r}$ & C57BL/6J & $s r / s r$ & 62 & 4 & $+/ s r$ & 63 & 3 \\
\hline jc & $\mathrm{C} 57 \mathrm{BL} / 6 \mathrm{~J}$ & $j c / j c$ & 40 & 5 & $+/ j C$ & 40 & 3 \\
\hline$C d h 23^{v-2 J}$ & $\mathrm{C} 57 \mathrm{BL} / 6 \mathrm{~J}$ & $v^{2 J} / v^{2 J}$ & 46 & 3 & & & \\
\hline PCdh15 $5^{a v-J}$ & $\mathrm{C} 57 \mathrm{BL} / 6 \mathrm{~J}$ & $a v^{J} / a v^{J}$ & 49 & 10 & $+/ a v^{J}$ & 49 & 7 \\
\hline Pcdh15 $5^{a v-2 J}$ & $\mathrm{C} 57 \mathrm{BL} / 6 \mathrm{~J} \times \mathrm{C} 3 \mathrm{HeB} / \mathrm{FeJ}$ & $a v^{2 J} / a v^{2 J}$ & 39 & 4 & $+/ a v^{2 J}$ & 40 & 2 \\
\hline Pcdh15 $5^{a v-3 J}$ & $\mathrm{C} 57 \mathrm{BL} / 6 \mathrm{~J}$ & $a v^{3 j} / a v^{3 j}$ & 98 & 4 & $+/ a v^{3 J}$ & 97 & 3 \\
\hline Sans ${ }^{j s}$ & $\mathrm{C} 57 \mathrm{BL} / 6 \mathrm{~J}$ & js/js & 30 & 4 & $+/ j s$ & 26 & 4 \\
\hline$O t \times 1^{j v}$ & $\mathrm{C} 57 \mathrm{BL} / 6 \mathrm{~J}$ & jv/jv & 36 & 4 & & & \\
\hline$h r$ & $\mathrm{HRS} / J$ & $h r / h r$ & 65 & 4 & & & \\
\hline$W n t 1^{s w}$ & $\mathrm{C} 57 \mathrm{BL} / 6 \mathrm{~J} \times \mathrm{C} 3 \mathrm{HeB} / \mathrm{FeJ}$ & $s w / s w$ & 55 & 2 & $+/ s w$ & 51 & 2 \\
\hline$K_{c n e} 1^{p k r}$ & $\mathrm{C} 57 \mathrm{BL} / 10 \mathrm{~J}$ & $p k r / p k r$ & 60 & 4 & $+/ p k r$ & 20 & 4 \\
\hline$Q k^{q k}$ & $\mathrm{C} 57 \mathrm{BL} / 6 \mathrm{~J} \times \mathrm{C} 3 \mathrm{HeB} / \mathrm{FeJ}$ & $q k / q k$ & $45 ; 67 ; 133$ & $4 ; 6 ; 4$ & $+/ q k$ & $37 ; 67$ & $1 ; 7$ \\
\hline$M b p^{\text {shi }}$ & $\mathrm{C} 3 \mathrm{HeB} / \mathrm{FeJ}$ & shi/shi & $26 ; 111$ & $4 ; 4$ & $+/$ shi & 117 & 2 \\
\hline Pou3f $4^{\text {del }}$ & $\mathrm{C} 3 \mathrm{HeB} / \mathrm{FeJ}$ & del/del & 88 & 2 & $+/ d e l$ & 88 & 2 \\
\hline Pou $34^{\text {del }}$ & $\mathrm{C} 3 \mathrm{HeB} / \mathrm{FeJ}$ & del/Y & 88 & 2 & $+/ Y$ & 89 & 2 \\
\hline Totals & 55 & & & 113 & & & 75 \\
\hline
\end{tabular}

Jackson Laboratory (Bar Harbor, ME), except for the $a v^{J}$ and $a v^{2 J}$ mice, which were from Case Western Reserve University (Cleveland, $\mathrm{OH}$ ). A portion of the data from $a v^{J}$ and $a v^{2 J}$ mice was documented by Alagramam et al. (2005) but are included here for comparison with the normative data and with the other strains measured herein. Data were collected at The Jackson Laboratory, the University of Missouri (Columbia, MO), and East Carolina University (Greenville, NC). The use of animals reported herein was reviewed and approved by the Institutional Animal Care and Use Committee at each institution. Ages at which testing was completed ranged from 20 to 120 days, with most strains tested between 30 and 60 days old (Table 2). The majority of strains were tested at only one age; therefore, neurodevelopmental changes or degenerative conditions could not be addressed. Two strains, $q k$ and $s h i$, were tested at two or three ages, respectively.

General cage behavior was documented and swimming behavior was recorded. For swimming behavior, mice were placed in an aquarium filled with tepid water and behavior was recorded for $15 \mathrm{~s}$ using a digital camera (Sony Mavica MVC-CD1000). Swimming was categorized as "good" if the animal swam at the surface of the water maintaining a horizontal bodyline and using the tail as a rudder. If the animal was able to swim at or near the surface of the water but with a body position other than horizontal, swimming was categorized as "fair." Swimming was considered "poor" if the animal was unable to maneuver adequately in the water and could not remain at the surface of the water. Animals in this latter category usually had to be rescued to prevent drowning. Drop reflexes were assessed by suspending each animal by the tail approximately 20 $\mathrm{cm}$ above a horizontal table surface. The mouse was quickly lowered toward the table surface and the animal's posture was observed. Drop reflexes were categorized as " + " if the animal demonstrated dorsiflexion and spread the front paws out in preparation to eventually land on the surface on their feet and in a proper body alignment. Drop reflexes were categorized as "-" if the animal displayed ventroflexion or some other body posture and would not land correctly if they reached the table surface.

For evoked potential electrophysiology, animals were weighed, anesthetized with EquiThesin $(4 \mu \mathrm{l} / \mathrm{g}$ body weight injected intraperitoneally) and a head mount was placed on the cranium using methods published previously (Jones and Jones 1999; Jones et al. 2002, 2004). The head mount was used to couple the cranium securely to a mechanical shaker for controlled movement of the head. Stainless steel electrodes were placed epidurally at the midline just posterior to the lamdoidal suture (noninverting 
electrode), subcutaneously behind the left and right pinnae (inverting electrodes), and at the neck (ground). Mice were positioned supine on a heating pad with the nose positioned upward and the head mount was coupled securely to the shaker platform. Core body temperature was maintained at $37 \pm 0.2^{\circ} \mathrm{C}$.

Gravity receptor neural function was assessed with linear VsEPs. Linear VsEPs are compound action potentials from the vestibular portion of the eighth nerve and central relays and are generated in response to linear acceleration transients. They can be recorded from the surface of the skull much like the widely used auditory brainstem response. In mammals, linear VsEPs depend strictly upon the utricle and saccule (gravity receptors) of the inner ear (Jones et al. 1999; Plotnik et al. 1999). The earliest response components (initial response peak) reflect activity of the peripheral vestibular nerve, whereas later response peaks reflect activity of vestibular relays within the brainstem and higher centers (Jones 1992; Nazareth and Jones 1998). Furthermore, VsEP amplitudes are linearly proportional to the amount of otoconia present in macular organs (Jones et al. 2004).

Vestibular stimuli and VsEP recording parameters for mice have been detailed elsewhere (Jones and Jones 1999; Jones et al. 2002, 2004). Briefly, stimuli were linear acceleration pulses, $2 \mathrm{~ms}$ duration, applied to the cranium in the naso-occipital $( \pm \mathrm{Gx})$ axis. Stimuli were presented at a rate of 16 pulses per second. Alternating stimulus polarity was used such that shaker motion "toggled" between upward and downward directions. Thus, head motion alternated in two directions along the naso-occipital axis. The output of a calibrated accelerometer, mounted on the shaker platform, was routed to an electronic differentiator to monitor the jerk component of the stimulus. Stimulus amplitude was quantified in decibels relative to $1.0 \mathrm{~g} / \mathrm{ms}\left(1.0 \mathrm{~g}=9.8 \mu \mathrm{m} / \mathrm{ms}^{2}\right)$. Maximum stimulus amplitude was $+6 \mathrm{~dB}$ re: $1.0 \mathrm{~g} /$ ms, which corresponds to a peak acceleration of $4 \mathrm{~g}$ and peak platform displacement of $26 \mu \mathrm{m}$.

VsEPs were recorded using traditional signal averaging. Electrophysiological activity was amplified $(200,000 \times)$, filtered $(300$ to $3000 \mathrm{~Hz},-6 \mathrm{~dB}$ points), and digitized $(125,000 \mathrm{~Hz})$ beginning at stimulus onset. Two hundred fifty-six responses were averaged to produce one response trace. Responses were replicated such that at least two waveforms were collected for each stimulus intensity. A threshold bracketing protocol was used where stimulus intensity began at $+6 \mathrm{~dB}$ and waveforms were collected in quiet and in the presence of an intense forward masker (50 to $50,000 \mathrm{~Hz}, 116 \mathrm{dBSPL}$ ). The masker was used to verify the absence of auditory responses. If the presence of auditory components was sus- pected, the masker remained on throughout the experimental protocol. After VsEPs were collected at $+6 \mathrm{~dB}$, the stimulus level was reduced in 6-dB steps until no response could be detected by visual inspection of the waveform. At that point, the stimulus intensity was reduced by an additional $3 \mathrm{~dB}$ and waveforms were collected for intensity steps midway between those already used. In this manner, we were able to collect an intensity series in 3-dB steps encompassing stimulus levels above and below threshold.

The first three response peaks were analyzed. Peak latencies were measured in microseconds from the onset of the stimulus to each response peak. Peak-topeak amplitudes were measured in microvolts from each positive response peak to its respective negative response peak. Threshold measured in $\mathrm{dB}$ re: $1.0 \mathrm{~g} /$ ms was defined as the stimulus level midway between the intensity just producing a discernible response and the stimulus level that did not. Thresholds provide a measure of the general sensitivity of the gravity receptor system. Latencies provide a measure of the timing of neural transmission and conduction through the vestibular neural pathways. Amplitudes represent the size of and general synchrony of the population of neurons responding to the stimulus.

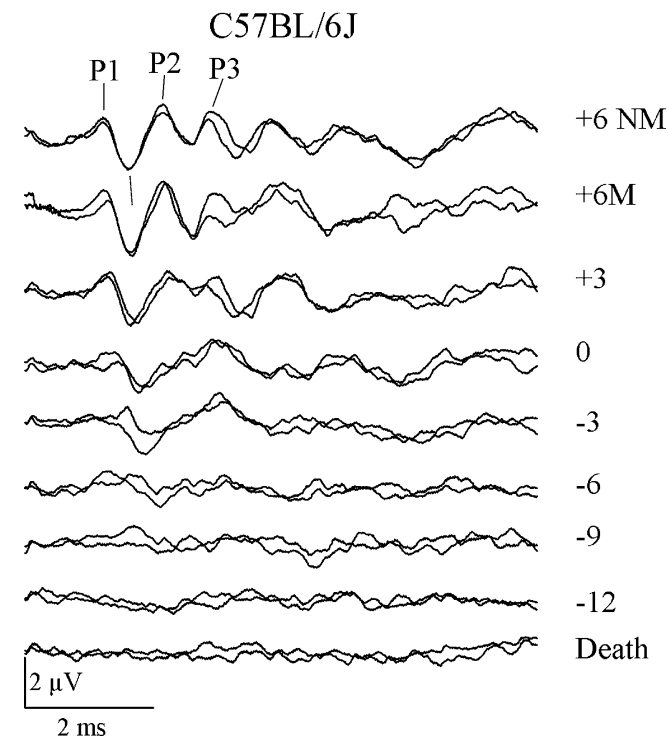

FIG. 1. Intensity series from one young $\mathrm{C} 57 \mathrm{BL} / 6$ ) mouse (35 days old). The first three positive response peaks are labeled. The first negative peak, N1, is denoted with a line. The top two trace pairs were obtained at the maximum jerk amplitude $(+6 \mathrm{~dB}$ re: $1.0 \mathrm{~g} / \mathrm{sm})$ without (NM) and with (M) intense acoustic masking. Response peaks increase in latency and decrease in amplitude as stimulus intensity is reduced until no response is visible at levels below threshold. Threshold here was scored at $-7.5 \mathrm{~dB}$ re: $1.0 \mathrm{~g} / \mathrm{ms}$. Total time represented for each waveform is $8 \mathrm{~ms}$. 
TABLE 3

Mutants in which no VsEPs could be detected at the maximum stimulus amplitude (+6 dB re: $1.0 \mathrm{~g} / \mathrm{ms})$, their drop reflexes, swimming ability, and general description of cage behavior

\begin{tabular}{|c|c|c|c|c|c|c|c|}
\hline \multirow[b]{2}{*}{ Mutation } & \multirow[b]{2}{*}{ Genotype } & \multirow[b]{2}{*}{$N$} & \multirow[b]{2}{*}{ Drop reflexes } & \multicolumn{3}{|c|}{ Swimming ability } & \multirow[b]{2}{*}{ Cage behavior } \\
\hline & & & & Good & Intermediate & Poor & \\
\hline$E s p n^{j e}$ & je/je & $5 / 5$ & - & & & 5 & \\
\hline Atp $2 b 2^{d f w-2 J}$ & $d f w^{2 J} / d f w^{2 J}$ & $4 / 4$ & - & & & 4 & \\
\hline$S p n b 4^{q v-3 J}$ & $q v^{3} / q v^{3 j}$ & $6 / 6$ & + & 4 & & & Quivering \\
\hline Spnb4 $4^{q v-I n d 2 J}$ & $q v^{\ln d 2 J} / q v^{\ln d 2 J}$ & $5 / 5$ & + & 5 & & & \\
\hline Myo $7 a^{\text {sh1 }}$ & $\operatorname{sh} 1 / \operatorname{sh} 1$ & $4 / 4$ & + & 2 & 2 & & Circling \\
\hline Myó $^{\text {sv }}$ & $S V / s V$ & $4 / 4$ & - & & & 4 & Circling \\
\hline$T m i e^{s r}$ & $s r / s r$ & $4 / 4$ & - & & & 4 & Circling \\
\hline jc & jc/jc & $5 / 5$ & + & 5 & & & Circling \\
\hline$C d h 23^{v-2 J}$ & $v^{2} / v^{2 J}$ & $3 / 3$ & - & & & 3 & Circling \\
\hline PCdh15av-J & $a v^{J} / a v^{J}$ & $10 / 10$ & DNT & & 3 & 7 & Circling \\
\hline Pcdh15 $5^{a v-2 J}$ & $a v^{2 J} / a v^{2 J}$ & $2 / 4$ & DNT & & & 2 & Circling \\
\hline Pcdh15 $5^{a v-3 J}$ & $a v^{3 j} / a v^{3 j}$ & $4 / 4$ & + and - & 1 & & 3 & Circling \\
\hline js & $j s / j s$ & $4 / 4$ & - & & & 4 & Circling \\
\hline$h r$ & $h r / h r$ & $4 / 4$ & + & 4 & & & Normal \\
\hline$K_{c n e} 1^{p k r}$ & $p k r / p k r$ & $4 / 4$ & - & & & 4 & Circling \\
\hline$K_{c n e} 1^{p k r}$ & $+/ p k r$ & $4 / 4$ & + & 4 & & & Normal \\
\hline$M b p^{s h i}$ & $+/ s h i$ & $1 / 2$ & + & 1 & & & Normal \\
\hline Pou3f del & $\mathrm{del} / \mathrm{Y}$ & $2 / 2$ & + & 2 & & & Head bob \\
\hline Pou3f del & $+/ Y$ & $1 / 2$ & + & 1 & & & Normal \\
\hline Pou $3 f^{\text {del }}$ & del/del & $2 / 2$ & + & 2 & & & Head bob \\
\hline Pou $3 f^{\text {del }}$ & +/del & $1 / 2$ & + & 1 & & & Normal \\
\hline & Totals & $79 / 84$ & & 32 & 5 & 40 & \\
\hline
\end{tabular}

$N$, Number of animals with absent VsEPs out of the total number of animals tested for that strain; DNT, did not test.

\section{RESULTS}

Screening VsEPs for one young C57BL/6J mouse (age 35 days) are shown in Figure 1, demonstrating the typical, normal waveform morphology. Three dominant peaks are typically visible within the first 4 to $6 \mathrm{~ms}$ after stimulus onset. Response peak latencies increase and peak amplitudes decrease until no response is visible at stimulus levels below threshold. Recordings from young C57 mice (35 days old) were

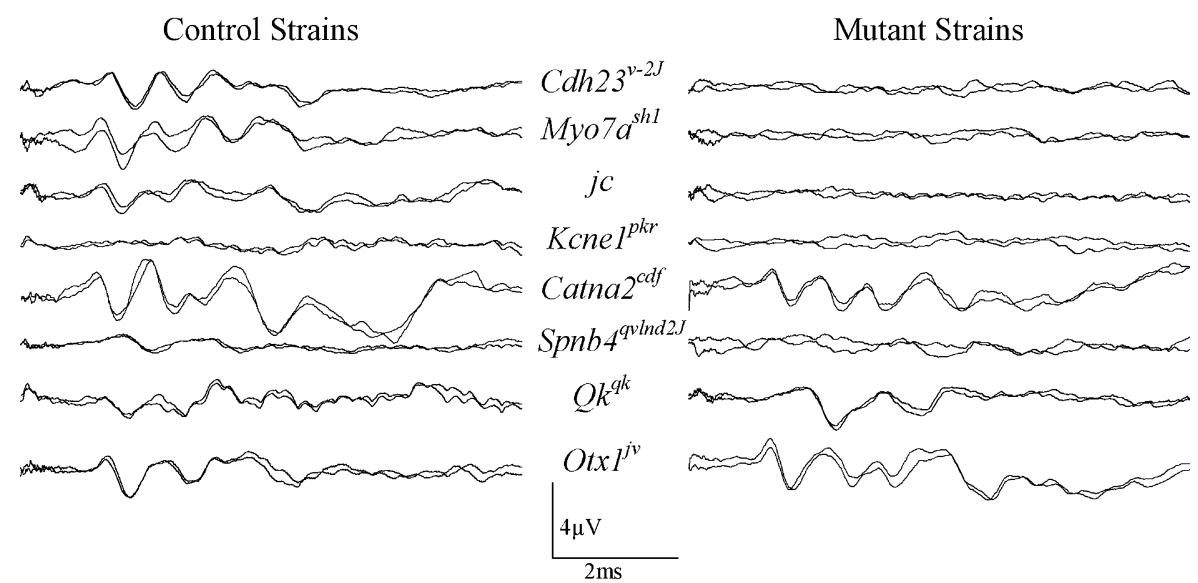

FIG. 2. Representative waveforms for eight mutant strains (right) and age matched controls (left). All responses shown here were recorded at $+6 \mathrm{~dB}$ re: $1.0 \mathrm{~g} / \mathrm{ms}$. Evident here are the absent responses typical for several of the mutant strains and prolonged latencies evident for $q k$ mice. Waveforms for the control strains were from the following background strains or heterozygotes (top to bottom): B6, B6, B6, +/pkr, +/cdf, +/qv ${ }^{\ln 2 J},+/ q k, \mathrm{~B} 6$. 
used to establish normative ranges for comparison and to verify normal function periodically during the screenings of mutant mice. Normative limits for VsEP thresholds obtained with screening protocols (i.e., 2 standard deviations above and below the mean) ranged from -5.5 to $-12.5 \mathrm{~dB}$ re: $1.0 \mathrm{~g} / \mathrm{ms}$. Normal limits for peak latencies were 1188 to $1740 \mu$ s for P1, 1996 to $2620 \mu$ s for P2, and 2888 to $3196 \mu$ s for P3. Normal ranges for VsEP amplitudes were 2.38 to $3.95 \mu \mathrm{V}$ for $\mathrm{P} 1 / \mathrm{N} 1$ and 1.20 to $3.23 \mu \mathrm{V}$ for $\mathrm{P} 2 / \mathrm{N} 2$. Response amplitudes often show the largest interand intrasubject variability among evoked potential response parameters; therefore, amplitudes that fell above or below the normal ranges were not considered abnormal unless threshold or latencies also fell outside normal ranges. Amplitude data are not shown; however, in general, amplitudes were inversely related to thresholds (i.e., elevated or poorer thresholds were accompanied by decreased response amplitudes particularly for the peripheral response component P1/N1).

VsEPs for the following homozygote mutations were absent at the maximum stimulus intensity used (i.e., $+6 \mathrm{~dB}$ re: $1.0 \mathrm{~g} / \mathrm{ms}): j e, d f w^{2 J}, q v^{\ln d 2 J}, q v^{3 J}, s h 1, s r$, sv, jc, mh, $a v^{J}, a v^{2 J}, a v^{3 J}, v^{2 J}, j s, h r, K c n e 1^{p k r}$, and Pou $34^{d e l}$ (Table 3, Fig. 2). One mutation $\left(a v^{2 J}\right)$ showed considerable variability in VsEPs, ranging from no response in two animals to measurable, but abnormal, responses in two others. A few heterozygotes $\left(+/\right.$ Pou $3 f 4^{d e l},+/$ Kcne $^{p k r},+/$ shi $)$ also lacked responses, suggesting profound deficits for these animals. Mice with absent VsEPs showed the most variability in swimming and drop reflexes. In fact, swimming and drop reflex results were equivocal. Fifty-one percent of mice with absent VsEPs could not swim; however, $47 \%$ showed good or intermediate swimming. Swimming data were unavailable for two mice with absent VsEPs.

All mice with measurable VsEPs, even if grossly abnormal, showed good swimming behavior and normal cage behavior and drop reflexes. Overall, behavior was not a good indicator of VsEP response parameters. Figures 3 and 4 show VsEP thresholds and response peak latencies, respectively. On average, the following background strains and genotypes and fell within normal ranges for all response parameters (i.e., thresholds, amplitudes and latencies): C57BL/6J (190 days old), C3H/HeSnJ, BALB/ $\mathrm{cByJ}, \mathrm{C} 3 \mathrm{HeB} / \mathrm{FeJ}, c d f / c d f,+/ q v^{3 J},+/ s r,+/ j c,+/ a v^{J},+/$ $a v^{3 J}, j v / j v,+/ s w,+/ q k$. Background strains and genotypes with one or more mean response parameters outside normal ranges compared to young C57 mice (abnormality described in parentheses) were DBA/2J (elevated thresholds), +/je (elevated thresholds) $+/ l c$ (elevated threshold, reduced amplitudes), $h o^{4 J} / h o^{4 J}$ (elevated threshold, reduced amplitudes),
$+/ c d f$ (improved threshold), $+/ d f w^{2 J}$ (elevated threshold, reduced amplitudes), $+/ \ln d^{2 J}$ (elevated threshold, prolonged latencies for central response peaks), $+/ s v$ (elevated threshold, reduced amplitudes),$+/ j s$ (elevated threshold, reduced amplitudes), $s w / s w$ (elevated threshold, absent central response peaks), $q k / q k$ (prolonged latencies for all peaks for all age groups, larger amplitudes for P1/N1), elderly $+/ s h i$ (elevated threshold, absent central response peaks), and shi/shi (elevated threshold for older age group, prolonged latencies for central response peaks for young and old age groups).

In addition to comparisons to normative data from young C57 mice (35 days old), some comparisons were made between heterozygote and homozygote groups of the same strain or between mutant and respective background strains. Statistical comparisons were not completed between homozygotes and heterozygotes when one or both groups evidenced absent VsEPs, which was the majority of strains. Homozygous and heterozygous strains with measurable VsEPs and sufficient data for statistical analysis included $c d f$ and $q k$ (67 days old). For $c d f$ mice, peak latencies and peak-to-peak amplitudes were not significantly different between homozygotes and heterozygotes; however, VsEP thresholds were significantly higher for $c d f / c d f$ homozygotes $[t=4.05, p=$ $0.007(d f=7)]$. Interestingly, thresholds were within normative ranges and similar to background strain thresholds $(\mathrm{C} 3 \mathrm{H} / \mathrm{HeSnJ})$ for the $c d f / c d f$ group $(-8.1$ $\mathrm{dB}$ re: $1.0 \mathrm{~g} / \mathrm{ms})$, but the $+/ c d f$ group had a mean VsEP threshold $(-15 \mathrm{~dB}$ re: $1.0 \mathrm{~g} / \mathrm{ms}$, see Fig. 3) more than 2 standard deviations better than the mean threshold for young $\mathrm{C} 57$ mice and their $\mathrm{C} 3 \mathrm{H} /$ HeSnJ background strain.

For $q k$ mice (67 days old), thresholds were virtually identical among heterozygous, homozygous, and background strain animals $(\mathrm{C} 3 \mathrm{HeB} / \mathrm{FeJ})$, but $q k$ homozygotes had significantly prolonged latencies for all response peaks (see Fig. 4, MANOVA, $p<$ 0.001). Interestingly, peak amplitudes for $\mathrm{P} 1 / \mathrm{N} 1$ were significantly larger for $q k$ homozygotes (mean amplitudes for $\mathrm{P} 1 / \mathrm{N} 1$ were $5.73 \mu \mathrm{V}$ for $q k / q k$ versus $2.82 \mu \mathrm{V}$ for $+/ q k$ ).

There were no significant differences in thresholds between mutants and their respective background strains for the following: C57BL/6J (35 and 190 days): $+/ j c,+/ a v^{J},+/ a v^{2 J},+/ a v^{3 J}, j v / j v,+/ q k$ (67 days) and $q k / q k$ (67 days); DBA/2J: ho4/ho4j; $\mathrm{C} 3 \mathrm{H} / \mathrm{HeSnJ}: c d f / c d f ; \mathrm{BALB} / \mathrm{cByJ}:+/ d f w^{2 J}$; $\mathrm{C} 3 \mathrm{HeB} /$ FeJ: shi/shi (26 days), $+/ q k$ (67 days) and $q k / q k(67$ days). Thresholds were significantly elevated for $+/ j s$ and $+/ s v$ in comparison to the $\mathrm{C} 57 \mathrm{BL} / 6 \mathrm{~J}$ background strain. The $+/ l c$ strain also had VsEPs significantly higher than C57 and CBA/CaJ background strains. 

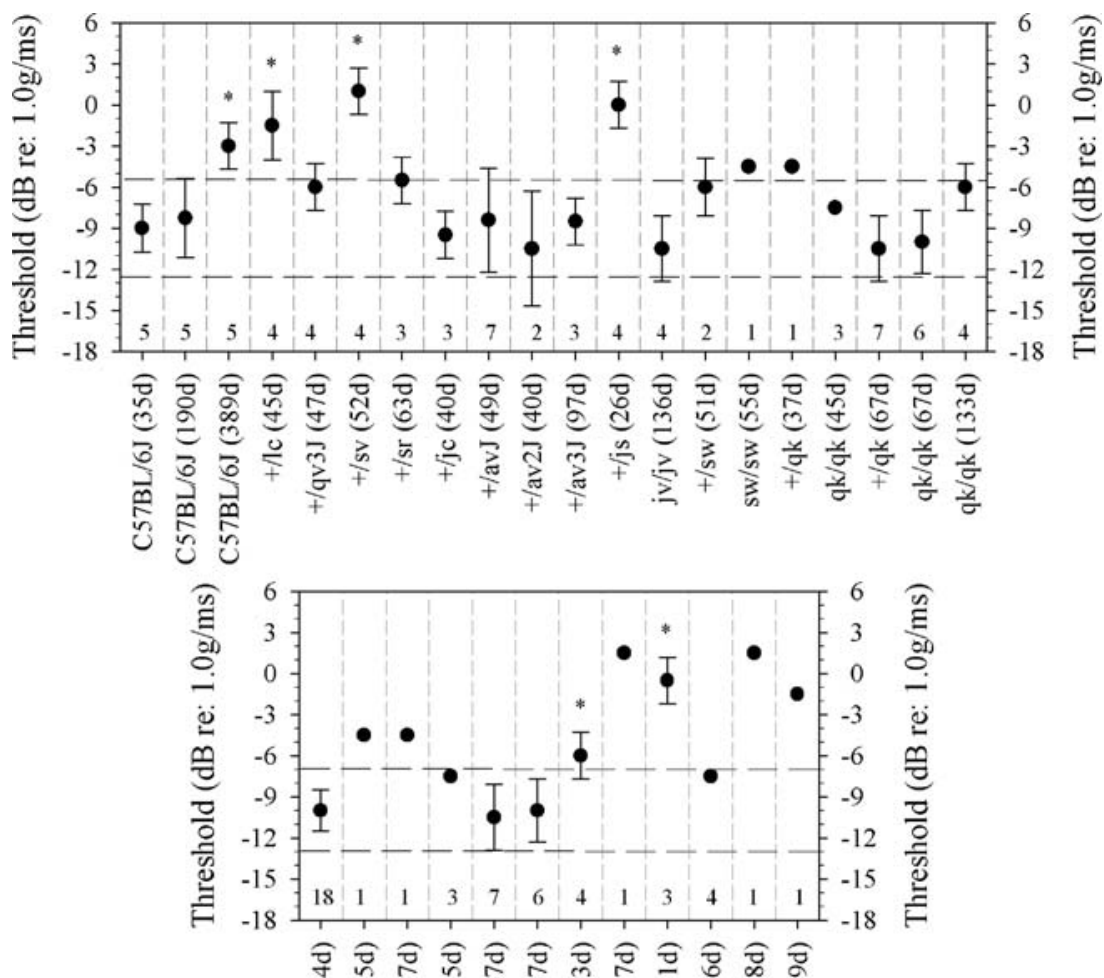

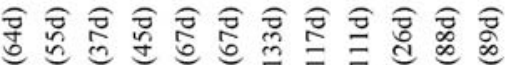
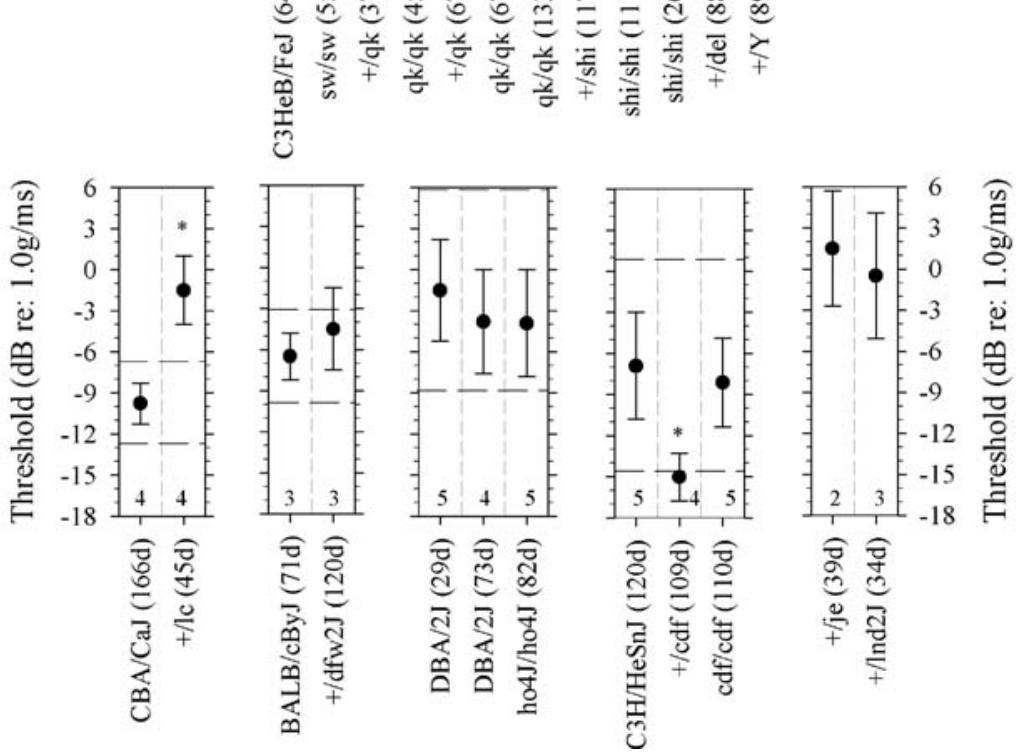

FIG. 3. Mean VsEP thresholds ( \pm 1SD) for homozygote and

$+/$ Ind2J and these two strains are shown together in the lower right panel. Thresholds provide a measure of the general sensitivity of the macular organs. Note the heterozygotes that show elevated thresholds in comparison to B6 normative ranges or their respective background strain. Asterisks represent those strains whose thresholds were significantly higher than the background strain threshold or the respective heterozygote group. observations contributing to each mean is shown. Homozygote data can be compared with the heterozygote counterparts, respective background strain (shown in the first column of each panel), or compared to normative ranges $( \pm 2 \mathrm{SD}$ shown for each background strain). Background strain data were not available for $+/ j e$ and 

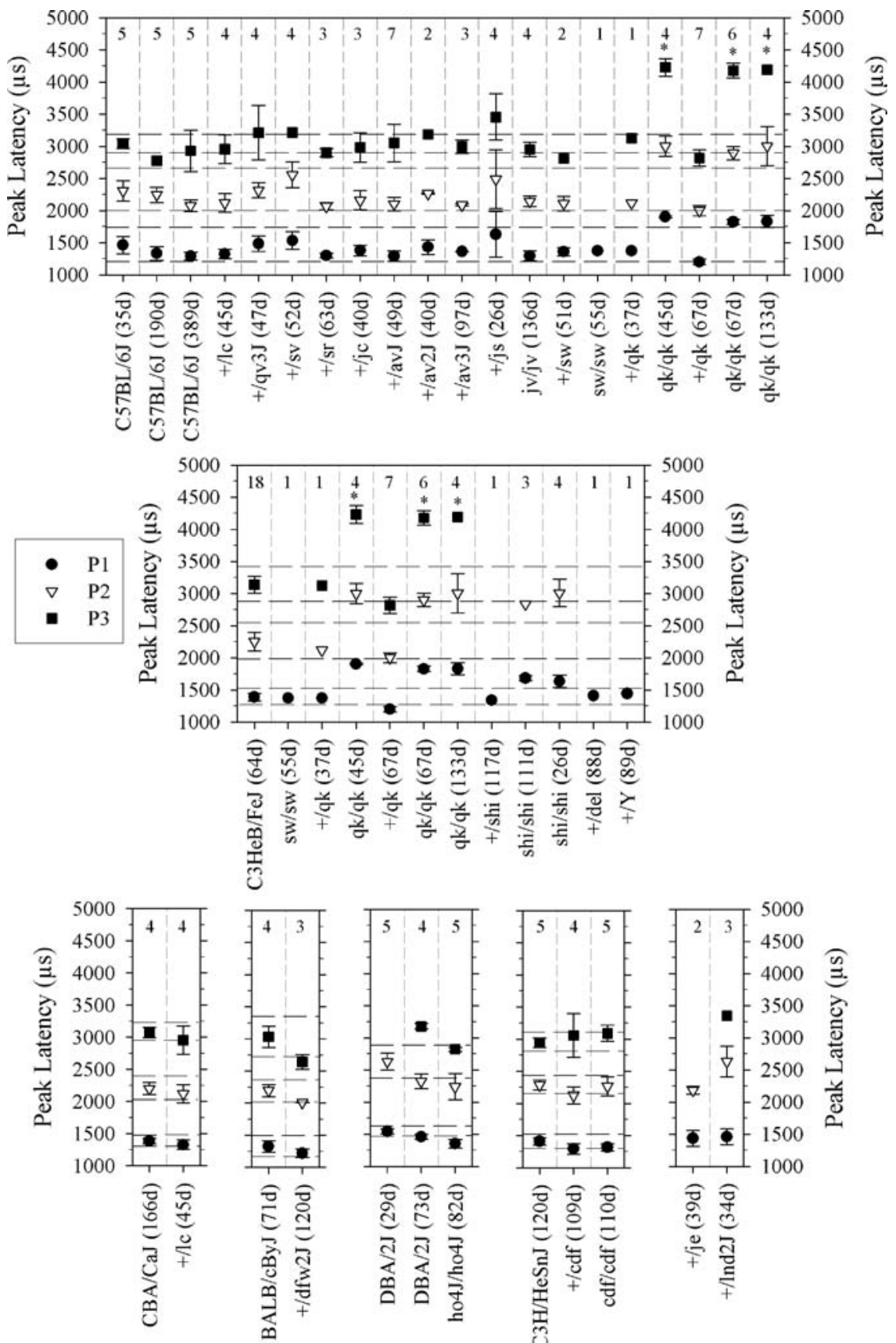

FIG. 4. Mean VsEP peak latencies $( \pm 1 \mathrm{SD})$ for homozygote and

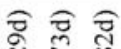

ปั and central (P2, P3) response peaks are shown. The number of observations contributing to the means for $\mathrm{P} 1$ and $\mathrm{P} 2$ are shown. Observations for $\mathrm{P} 3$ were often equal to the number shown but may have been fewer in some cases as P3 is often quite variable. Normative ranges $( \pm 2 \mathrm{SD})$ for background strains are represented by the horizontal dashed lines in each panel. Respective background strains are shown in the first column of each panel. Background strain data were not available for $+/$ je and $+/ / n d 2 J$ and these two strains are shown together in the lower right panel. Asterisks represent those strains that were significantly different than the

background strain or their respective heterozygote group. Latency provides a measure of synaptic timing and neural conduction. Notable here are the demyelinating mutants (e.g., $q k$, shi), which show prolonged latencies either for central response peaks (e.g., shi/ shi) or both peripheral and central peaks (e.g., $q k / q k$ ). Prolonged latencies were also visible for some heterozygotes $(+/$ Ind2/). The absence of response peaks P2 and/or P3 for some strains could be indicative of central pathology, desynchrony, or the inability to resolve a replicable response peak from the background EEG activity. In particular, response peak P3 can be quite variable as discussed in the text. 


\section{DISCUSSION}

The functional measures conducted herein provide the first quantitative phenotyping of gravity receptor function for a relatively large number of mutant mouse strains. Some of these strains are used extensively for investigating various physiological disorders, including human syndromic and nonsyndromic hearing impairment (see Table 1). The present work also extends the total number of mutant strains that have been phenotyped with regard to gravity receptor function. Previously published data (Jones and Jones 1999, 2004) described gravity receptor function for six otoconia-deficient strains [head tilt $\left(N o x 3^{\text {het }}\right)$, pallid $\left(P l d n^{p a}\right)$, mocha $\left(A p d 3^{m h}\right)$, muted $\left(\right.$ Muted $\left.{ }^{m u}\right)$, tilted $\left(O t o p 1^{t l t}\right)$, and lethal milk $\left.\left(\operatorname{Slc} 30 a 4^{l m}\right)\right]$. Furthermore, the present data provide important information in three areas. First, the data confirm profound gravity receptor deficits for a number of mouse strains with significant structural deficits of the inner ear. For example, hair cell structural deficits in myosin, adherens junction, and scaffolding proteins $\left(M y o 7 a^{s h 1}, M y o 6 a^{s v}, C d h 23^{v-2 J}\right.$, $\mathrm{Sans}^{j}{ }^{\mathrm{s}}$ ), ion transport deficits in various cell types $\left(\mathrm{K} c n e 1^{p k r}, A t p 2 b 2^{d f w-2 J}\right)$, and abnormal inner ear morphogenesis $\left(P o u 3 f 4^{d e l}\right.$, Tmie $e^{s r}$ ) all result in absent VsEPs. Several of the studies listed in Table 1 showed profound cochlear and auditory impairments for these strains as well. In other cases, however, detailed examination of the vestibular apparatus of the mutant mice failed to show any obvious structural correlate for the vestibular dysfunction (e.g., Pcdh15 ${ }^{a v}$, Alagramam et al. 2005). Interestingly, the present results show absent VsEPs in two strains where inner ear structural deficits are unknown $(j c$, $h r)$. Hearing function measured with auditory brainstem response (ABR) has demonstrated profound hearing impairment for $j c$ homozygotes by 1 month of age, whereas $h r$ homozygotes demonstrate normal ABR thresholds up to 6 months (K. Johnson, personal communication). Behaviorally, $j c$ is known to demonstrate head bobbing and other behavioral abnormalities but can swim (Southard, 1970). The hairless gene is expressed in skin and brain (CachonGonzalez et al. 1994); however, inner ear expression is unknown. Functionally, $h r$ mice were shown to develop hyperkeratosis and immunodeficiency (Reske-Kunz et al. 1979; Morrissey et al. 1980).

Absent evoked potentials do not necessarily mean complete loss of function. Synchronous firing of a population of neurons produces a volley of action potentials. This is the necessary underlying neurophysiology for the generation of evoked potentials, particularly short-latency potentials. Therefore, the absence of evoked potentials could be due to profound end organ pathology or lack of syn- chronicity in the neural population. It is well known that the central nervous system compensates or "recalibrates" in response to loss of input from the vestibular periphery. Therefore, it is not surprising that behavior may vary widely in animals with absent VsEPs. Indeed, absent VsEPs in conjunction with normal swimming or drop reflex behavior suggests that even a small amount of sensory input is sufficient for vertical orientation.

Many of the strains with absent VsEPs serve as models for human syndromic and nonsydromic hearing impairment. Therefore, one might ask how vestibular function compares in the human and mouse disorders. The present mouse data suggest that vestibular dysfunction may be prevalent in these disorders. It is well known that Usher syndrome type 1 has vestibular areflexia and the absent VsEPs for the mouse strains $M y o 7 a^{s h 1}, P c d h 15^{a v}, S_{a n s}{ }^{j s}$, and $C d h 23^{v-2 J}$ are consistent with the human data. However, little to no human vestibular data have been published for most genetic forms of hearing loss, particularly nonsyndromic forms. This is likely due to several reasons. First, relatively few investigators are systematically looking for vestibular impairment. Second, vestibular assessment is often not part of routine phenotyping in suspected cases of hereditary abnormalities. Third, if vestibular impairment is present at birth or deficits appear gradually, the nervous system likely compensates for the altered vestibular input, making any deficit undetectable via case histories, questionnaires, or behavioral observations. In cases where motor delays or imbalance behaviors are apparent, vestibular function is often not tested as a possible etiology so the functional status of the vestibular periphery remains unknown. Finally, current clinical tests of vestibular function do not directly assess inner ear function, but rather, evaluate the final motor output of the eyes or balance control systems. Such measures encompass the input, integration, and output components of nervous system function, making it more difficult to ascertain the functional status of the vestibular periphery. Estimates of hearing-impaired children with vestibular dysfunction range from 28 to $77 \%$ among those with hearing impairment of various causes (Steel 1991) and 34\% among children with hereditary hearing impairment (Arnvig 1955). The present data suggest that vestibular dysfunction may be more prevalent and perhaps vestibular testing should be a more regular component in the workup of genetic hearing loss.

Most, but not all, of the animals with profound deficits (i.e., absent VsEPs) showed abnormal cage and/or swimming behaviors. Indeed, many phenotyping strategies use behavior as an indicator of inner ear vestibular deficits. However, whereas mice often 
show behaviors suggestive of balance problems (e.g., head bobbing, wobbling, circling behavior), these observations are indirect indicators of inner ear function and can, in fact, be due to abnormalities that are unrelated to the inner ear end organs. For example, circling and hyperactive behaviors have been documented in mice with drug- or lesioninduced changes in dopaminergic brain regions (e.g., striatum, Pycock et al. 1975; Watanabe et al. 1981; Toyoshi et al. 1995). Fitzgerald et al. (1991, 1992, 1993) identified and characterized a transgenic insertional mutant mouse strain, known as chakragati $(c k r)$. They found no evidence of vestibular or cochlear defects as the source of circling, hyperactivity, and altered posture (Ratty et al. 1990; Fitzgerald et al. 1991), but instead attributed behaviors to bilateral asymmetries in striatal dopamine receptors (Fitzgerald et al. 1993). These examples underscore the fact that circling and hyperactive behaviors may not be exclusive to and definitive for inner ear vestibular defects. Moreover, the absence of significant behavioral deficits may mask occult vestibular dysfunction as discussed above.

Second, the present data identify several homozygote and heterozygote mutations with mild to severe loss of function (i.e., functional deficits other than profound) and further suggest that the deficit affects the otolithic organs (utricle and/or saccule) or their neural pathways. Deficits evident in heterozygotes might suggest a dominant mutant allele. Importantly, these deficits were not associated with overt imbalance and may have remained undetected based on behavioral observation alone. It is reasonable to suppose that compensatory mechanisms in the central nervous system have "recalibrated" the motor control systems to offset the reduced input from the periphery.

Third, the results confirm normal gravity receptor function for several mutants. The Jackson waltzer $(j v)$ is one homozygote mutation where normal gravity receptor function is evident. This mutation demonstrates circling behavior and a structural absence of the lateral semicircular canal (Dickie and Deol 1966). It does not show any hearing impairment (Dickie and Deol 1966) and the present data demonstrate normal VsEP parameters suggesting normal utricular and saccular function. Cerebellar deficient folia homozygotes $(c d f / c d f)$ also demonstrated normal gravity receptor function.

The functional deficit can also take many forms. For example, not all of the functional deficits are exclusively a loss of sensitivity (i.e., elevated thresholds). The demyelinating mutants $(q k / q k, s h i / s h i)$ do not demonstrate elevated thresholds (until old age) but show dramatic prolongation of VsEP response peak latencies. $Q k$ and $s h i$ demonstrate prolongation of all peak latencies since this deficit results in abnormal myelin in peripheral and central neurons, although central myelin abnormalities are more severe than peripheral abnormalities (Sidman et al. 1964; Chernoff 1981).

Two strains with cerebellar defects $\left(h o^{4 J}\right.$ and $\left.l c\right)$ have mutations in the gene encoding ionotropic glutamate receptor delta 2, which is thought to be expressed exclusively in the cerebellum (Zuo et al. 1997). These two strains also demonstrated mildly elevated thresholds suggestive of a peripheral deficit; however, the threshold for $h o^{4 J}$ was identical to the DBA/2J background strain suggesting that the elevated thresholds for $h o^{4 J}$ are due to the genetic background and not to the $h o^{4 J}$ mutation. In fact, DBA/2J is known to be homozygous for mutations in $C d h 23^{\text {ahl }}$. The present study shows that null mutations in $C d h 23$ lead to profound deficits $\left(v^{2 J}\right.$, Table 2). Cdh23 has been reported to be a component of tip links in sensory hair cells (Siemens et al. 2004; Sollner et al., 2004); however, more recent reports suggest that $C d h 23$ is associated with transient lateral links in the developing hair bundles of cochlear sensory cells (Michel et al. 2005; Lagziel et al. 2005). Interestingly, $+/ l c$ is maintained on a $\mathrm{C} 57 \times \mathrm{CBA}$ background, and both of these strains (C57BL/6J and CBA/CaJ) have normal VsEPs up to at least 190 days old. At present, there is no reason to suspect that the F1 hybrids would be responsible for the elevated threshold seen $+/ l c$. Although the cerebellum plays an important role in vestibular function, further study is necessary to understand why a Grid2 mutation in the $+/ l c$ strain may express a peripheral deficit.

Although the present results provide data for vestibular function among mutant mouse strains, a number of questions remain for further study. First, what might more detailed analysis reveal for those strains identified with deficits? Screening results do not characterize a deficit completely; rather they often call for further testing. So for those strains identified with measurable deficits, what is the exact nature of the deficit? What are the onset, time course, and progression of the dysfunction? Second, how might gravity receptor neural function change with senescence? The present results show function at a given point in the life span. Whereas some strains showed normal function at the ages screened, would function remain normal into advanced age? These questions are being investigated in terms of agerelated hearing loss, and indeed, several mouse strains carry genes that have been shown to contribute to or modify aging of hearing function (Johnson et al. 1997, 2000; Johnson and Zheng 2002). We are currently evaluating similar questions for vestibular function and further are making a comparison 
between the two inner ear sensory systems in terms of functional senescence.

In summary, the present results provide information about gravity receptor function for a variety of mutant mouse strains. The results also provide a unique perspective that behavioral tests may not reveal. VsEP measures are slower and more time consuming than behavioral screenings; however, they provide additional information that can broaden the context of behavioral findings and extend our understanding of vestibular dysfunction in relation to genetic mutations. They also provide information that often cannot be gleaned from behavior alone.

\section{ACKNOWLEDGMENTS}

NIH R01 DC04477 supported this work. NIH RO1 DC05385 (to K.A.) supported part of the work related to Ames waltzer mice. The authors thank W. Avniel, M. Hartsock, P. Bell, and K. Tregear for excellent technical as-sistance. Portions of this work were presented at the 2003 Association for Research in Otolaryngology Midwinter Meeting.

\section{REFERENCES}

Ahmed ZM, Riazuddin S, Ahmad J, Bernstein SL, Guo Y, Sabar MF, Sieving P, Riazuddin S, Griffith AJ, Friedman TB, Belyantseva IA, WILCOX ER. PCDH15 is expressed in the neurosensory epithelium of the eye and ear and mutant alleles are responsible for both USH1F and DFNB23. Hum. Mol. Genet. 12(24):32153223, 2003.

Alagramam KN, Murcia Cl, Kwon HY, Pawlowski KS, Wright CG, Woychik RP. The mouse Ames waltzer hearing-loss mutant is caused by mutation of Pcdh15, a novel protocadherin gene. Nat. Genet. 27:99-102, 2001a.

Alagramam KN, Yuan H, Kuehn MH, Murcia Cl, Wayne S, Srisailpathy CRS, Lowry RB, Knaus R, van Laer L, Bernier FP, Schwartz S, Lee C, Morton CC, Mullins RF, Ramesh A, Van Camp G, Hagemen GS, Woychik RP, Smith RJH. Mutations in the novel protocadherin PCDH15 cause Usher syndrome type 1F. Hum. Mol. Genet. 10:1709-1718, 2001b.

Alagramam KN, Stahl JS, Jones SM, Pawlowski KS, Wright CG. Characterization of vestibular dysfunction in the mouse model for Usher Syndrome 1F. J. Assoc. Res. Otolaryngol. 6(2):106$118,2005$.

ANNIKo M, Sobin A, Wersall J. Vestibular hair cell pathology in the Shaker-2 mouse. Arch. Otorhinolaryngol. 226:45-50, 1980.

ARNVIG J. Vestibular function in deafness and severe hardness of hearing. Acta Otolaryngol. 45:283-288, 1955.

Avraham KB. Mouse models for deafness: lessons for the human inner ear and hearing loss. Ear Hear. 24:332-341, 2003.

Avraham KB, Hasson T, Steel KP, Kingsley DM, Russell LB, Mooseker MS, Copeland NG, Jenkins NA. The mouse Snell's waltzer deafness gene encodes an unconventional myosin required for structural integrity of inner ear hair cells. Nat. Genet. 11:369-375, 1995.

BALE SJ. Of hairless mice and men: the genetic basis of congenital alopecia universalis/congenital atrichia. J. Cutan. Med. Surg. 3(6):309-311, 1999.
Ballarino J, Howland HC. Studies of otoconial development in a "giant-crystal" strain of chicks using scanning electron microscopy, polarized light microscopy, and X-ray crystallography. Scan. Electron Microsc. Pt. 4:1667-1680, 1986.

Bergstrom RA, You Y, Erway LC, Lyon MF, Schimenti JC. Deletion mapping of the head tilt (het) gene in mice: a vestibular mutation causing specific absence of otoliths. Genetics 150:815-822, 1998.

Bohmer A. Short latency vestibular evoked responses to linear acceleration stimuli in small mammals: masking effects and experimental applications. Acta Otolaryngol. Suppl. 520:120-123, 1995.

Bronson RT, Sweet HO, Spencer CA, Davisson MT. Genetic and age related models of neurodegeneration in mice: dystrophic axons. J. Neurogenet. 8:71-83, 1992.

Cable J, Barkway C, Steel KP. Characteristics of stria vascularis melanocytes of viable dominant spotting ( $\mathrm{Wv} / \mathrm{Wv})$ mouse mutants. Hear. Res. 64:6-20, 1992.

Cable J, Huszar D, Jaenisch R, Steel KP. Effects of mutations at the $W$ locus (c-kit) on inner ear pigmentation and function in the mouse. Pigment Cell Res. 7:17-32, 1994.

Cachon-Gonzalez MB, Fenner S, Coffin JM, Moran C, Best S, Stoye JP. Structure and expression of the hairless gene of mice. Proc. Natl. Acad. Sci. U.S.A. 91:7717-7721, 1994.

CHERnoff GF. Shiverer: an autosomal recessive mutant mouse with myelin deficiency. J. Hered. 72:128, 1981.

Cook SA, Johnson KR, Zheng QY, Davisson MT. Jackson waltzer ( jv) maps to Chromosome 11 and is an allele of the $\operatorname{Otx} 1$ gene. Mouse Mutant Resource Web site article. http://www.jax.org/ mmr/mmr_mutant_jv.html, 2003.

Dememes D, SAns A. Pathological changes during the development of the vestibular sensory and ganglion cells of the Bronx waltzer mouse. Scanning and transmission electron microscopy. Brain Res. 350:285-295, 1985.

Deol MS. The anomalies of the labyrinth of the mutants variantwaddler, shaker-2, and jerker in the mouse. J. Genet. 52:562588, 1954.

De Zeeuw Ci, van Alphen AM, Koekkoek SK, Buharin E, Coesmans MPH, Morpurgo MM, van den Burg J. Recording eye movements in mice: a new approach to investigate the molecular basis of cerebellar control of motor learning and motor timing. Otolaryngol. Head Neck Surg. 199(3):193-203, 1998.

Dickie MM, Deol MS. Jackson waltzer, $j v$. Mouse News Lett. 35:31, 1966.

Dipalma F, Holme RH, Bryda EC, Belyantseva ia, Pellegrino R, Kachar B, Steel KP, Noben-Trauth K. Mutations in Cdh23, encoding a new type of cadherin, cause stereocilia disorganization in waltzer, the mouse model for Usher syndrome type 1D. Nat. Genet. 27:103-107, 2001.

Elidan J, Langhofer L, Honrubia V. Recording of short-latency vestibular evoked potentials induced by acceleration impulses in ex-perimental animals: current status of the method and its applications. Electroencephalogr. Clin. Neurophysiol. 68:5869, 1987.

ErWAY LC, Grider A. Zinc metabolism in lethal-milk mice. Otolith, lactation, and aging effects. J. Hered. 75:480-484, 1984.

Fitzgerald LW, Ratty AK, Moller KJ, Ellsworth MK, Glick SD, Gross KW. Ontogeny of hyperactivity and circling behavior in a transgenic insertional mutant mouse. Behav. Neurosci. 105:755763, 1991.

Fitzgerald LW, Miller KJ, Ratty AK, Glick SD, Teitler M, Gross KW. Asymmetric elevation of striatal dopamine $D_{2}$ receptors in the chakragati mouse: neurobehavioral dysfunction in a transgenic insertional mutant. Brain Res. 580:18-26, 1992.

Fitzgerald LW, Ratty AK, Teitler M, Gross KW, Glick SD. Specificity of behavioral and neurochemical dysfunction in 
the chakragati mouse: a novel genetic model of a movement disorder. Brain Res. 608:247-258, 1993.

Gibson F, Walsh J, Mburu P, Varela A, Brown KA, Antonio M, Beisel KW, Steel KP, Brown SD. A type VII myosin encoded by the mouse deafness gene shaker-1. Nature 374:62-64, 1995.

Gleich O, Dooling RJ, Manely GA. Inner-ear abnormalities and their functional consequences in Belgian Waterslager canaries (Serinus canarius). Hear. Res. 79:125-136, 1994a.

Gleich O, Klump GM, Dooling RJ. Hereditary sensorineural hearing loss in a bird. Naturwissenschaften 81:320-323, 1994b.

Gleich O, Klump GM, Dooling RJ. Peripheral basis for the auditory deficit in Belgian Waterslager canaries. Hear. Res. 82:100-108, 1995.

Grusser-Cornehls U, Luy M, Baurle J. Electrophysiology and GABA-immunocytochemistry in the vestibular nuclei of normal (C57BL/6J) and Leaner mutant mice. Brain Res. 703:51-62, 1995.

Henry KR, McGinn MD. The mouse as a model for human audition. A review of the literature. Audiology 31:181-189, 1992.

Jackson T, Thomas J, Greed ED, Noben-Trauth K. Genetic and physical maps of jerker (Espn(je)) on mouse chromosome 4 . Biochem. Biophys. Res. Commun. 296(5):1143-1147, 2002.

JOHNSON KR, ZHENG QY. Ahl2, a second locus affecting age-related hearing loss in mice. Genomics 80:461-464, 2002.

Johnson KR, Erway LC, CoOK SA, Willott JF, Zheng QY. A major gene affecting age-related hearing loss in C57BL/6J mice. Hear. Res. 114:83-92, 1997.

Johnson KR, Zheng QY, ERWAY LC. A major gene affecting agerelated hearing loss is common to at least ten inbred strains of mice. Nat. Genet. 27:191-194, 2000.

JonEs TA. Vestibular short latency responses to pulsed linear acceleration in unanesthetized animals. Electroencephalogr. Clin. Neurophysiol. 82(5):377-386, 1992.

Jones TA, Jones SM. Short latency compound action potentials from mammalian gravity receptor organs. Hear. Res. 136:75-85, 1999.

Jones SM, Ryals BM, Colbert S. Vestibular function in Belgian Waterslager canaries. Hear. Res. 121:161-169, 1998.

Jones SM, Erway LC, Bergstrom RA, Schimenti JC, Jones TA. Vestibular responses to linear acceleration are absent in otoconiadeficient C57BL/6JE $i$-het mice. Hear. Res. 135:56-60, 1999.

Jones SM, Subramanian G, Avniel W, Guo Y, Burkard RF, Jones TA. Stimulus and recording variables and their effects on mammalian vestibular evoked potentials. J. Neurosci. Methods 118:2331, 2002.

Jones SM, ERway LC, YU H, Johnson KR, Jones TA. Gravity receptor function in mice with graded otoconial deficiencies. Hear. Res. 191:34-40, 2004.

Kikkawa Y, Shitara H, Wakana S, Kohara Y, Takada T, Okamoto M, Taya C, Kamiya K, Yoshikawa Y, Tokano H, Kitamura K, Shimizu K, Wakabayashi Y, Shiroishi T, Kominami R, Yonekawa H. Mutations in a new scaffold protein Sans cause deafness in Jackson shaker mice. Hum. Mol. Genet. 12:453-461, 2003.

Kitamura K, Yagi M, Yoshikawa Y, Ochidubo F, Kato M. Vestibular pathology in a new-mutant mouse. Acta Otolaryngol. Suppl. 481:121-124, 1991.

Kitazawa H, Katoh A, Yagi T, Nagao S. Dynamic characteristics and adaptability of reflex eye movements of Fyn-kinase-deficient mice. Neurosci. Lett. 280(3):179-182, 2000.

Koekkoek SK, Van Alphen AM, van den Burg J, Grosveld F, Galjart $\mathrm{N}$, De ZeEuw CI. Gain adaptation and phase dynamics of compensatory eye movements in mice. Genes Funct. 1(3):175190, 1997.

Kozel PJ, Freidman RA, Erway LC, Yamoah EN, Liu LH, Riddle T, Duffy JJ, Doetschman T, Miller Ml, Cardell El, Shull GE. Balance and hearing deficits in mice with a null mutation in the gene encoding plasma membrane $\mathrm{Ca}^{2+}$-ATPase isoform 2. J. Biol. Chem. 273:18693-18696, 1998.

Krug R, Baurle J, Grusser-Cornehls U. Enlargement of GADimmunopositive terminals in the lateral vestibular nucleus (LVN) of weaver mutant mice. Histol. Histopathol. 10:105109, 1995.

Lagziel A, Ahmed ZM, Schultz JM, Morell RJ, Bleyantseva IA, FriEDMAN TB. Spatiotemporal pattern and isoforms of cadherin 23 in wild type and waltzer mice during inner ear hair cell development. Dev. Biol. 280(2):295-306, 2005.

Lalouette A, Guenet JL, Vriz S. Hotfoot mouse mutations affect the delta 2 glutamate receptor gene and are allelic to lurcher. Genomics 50:9-13, 1998.

Letts VA, Valenzuela A, Dunbar C, Zheng QY, Johnson KR, Frankei WN. A new spontaneous mouse mutation in the Kcnel gene. Mamm. Genome 11(10):831835, 2000.

Lockhart PJ, O'Farrell CA, Farrer MJ. It's a double knock-out! The quaking mouse is a spontaneous deletion of parkin and parkin co-regulated gene (PACRG). Mov. Disord. 19(1):101104, 2004.

LoRd EM, Gates WH. Shaker, a new mutation in the house mouse (Mus musculus). Am. Nat. Hist. 68:435-442, 1929.

Lyon MF. Absence of otoliths in the mouse: an effect of the pallid mutant. J. Genet. 51:638-650, 1953.

LyON MF, Meredith R. Muted, a new mutant affecting coat colour and otoliths of the mouse, and its position in linkage group XIV. Genet. Res. 14:163-166, 1969.

Lyon MF, Rastan S, Brown SDM. Genetic Variants and Strains of the Laboratory Mouse, Vols. 1 and 2. Oxford University Press, New York, 1996.

Malicki J, Schier AF, Sonica-Krezel L, Stemple KL, Neuhauss SC, Stainier DY, Abdelilah S, Rangini Z, Zwartkruis F, Driever W. Mutations affecting development of the zebrafish ear. Development 123:275-283, 1996.

Michel V, Goodyear RJ, Weil D, Marcotti W, Perfettini I, Wolfrum U, Kros CJ, Richardson GP, Petit C. Cadherin 23 is a component of the transient lateral links in the developing hari bundles of cochlear sensory cells. Dev. Biol. 280(2):281-294, 2005.

Mitchem KL, Hibbard E, Beyer LA, Bosom K, Dootz GA, Dolan DF, Johnson KR, Raphael Y, Kohrman DC. Mutation of the novel gene Tmie results in sensory cell defects in the inner ear of spinner, a mouse model of human hearing loss DFNB6. Hum. Mol. Genet. 11:1887-1898, 2002.

Molineaux SM, Engh H, deFerra F, Hudson L, Lazzarini RA. Recombination within the myelin basic protein gene created the dysmyelinating shiverer mouse mutation. Proc. Natl. Acad. Sci. U.S.A. 83(19):7542-7546, 1986.

Moriyama K, Hashimoto R, Hanai A, Yoshizaki N, Yonezawa S, Otani $\mathrm{H}$. Degenerative hairlets on the vestibular sensory cells in mutant bustling (BUS/Idr) mice. Acta Otolaryngol. 117:20-24, 1997.

Morrissey PJ, Parkinson DR, SchWARTZ RS, WaKsal SD. Immunologic abnormalities in HRS/J mice. Specific deficit in T lymphocyte helper function in a mutant mouse. J. Immunol. 125, 15581562, 1980.

Morton CC. Genetics, genomics and gene discovery in the auditory system. Hum. Mol. Genet. 11(10):1229-1240, 2002.

NAZARETh AM, Jones TA. Central and peripheral components of short latency vestibular evoked potentials. J. Vestib. Res. 8(3):233-252, 1998.

Nicolas MT, Dememes D, Martin A, Kupershimdt S, Barhanin J. KCNQ1/KCNE1 potassium channels in mammalian vestibular dark cells. Hear. Res. 153:132-145, 2001.

Norman DJ, Feng L, Cheng SS, Gubbay J, Chan E, Heintz N. The lurcher gene induces apoptotic death in cerebellar Purkinje cells. Development 121:1183-1193, 1995. 
Ornitz DM, Bohne BA, Thalmann I, Harding GW, Thalmann R. Otoconial agenesis in tilted mutant mice. Hear. Res. 112:60-70, 1997.

Otani H, Moriyama K, Yonezawa S, Shoji R, Tanaka O. Vestibulocochlear defects and effects of deuterium oxide in mutant bustling (BUS) mice. Acta Otolaryngol. Suppl. 519:286-293, 1995.

Park C, Falls W, Finger JH, Longo-Guess CM, Ackerman SL. Deletion in Catna2, encoding alpha N-catenin, causes cerebellar and hippocampal lamination defects and impaired startle modulation. Nat. Genet. 31(3):279-284, 2002.

PARKINSON N, Brown SD. Focusing on the genetics of hearing: you ain't heard nothin' yet. Genome Biol. 3(6):1-6, 2002.

Parkinson NJ, Olsson CL, Hallows JL, McKee-Johnson J, Keogh BP, Noben-Trauth K, Kujawa SG, Tempel BL. Mutant beta spectrin 4 causes auditory and motor neuropathies in quivering mice. Nat. Genet. 29:61-65, 2001.

Plotnik M, Sichel JY, Elidan J, Honrubia V, Sohmer H. Origins of the short latency vestibular evoked potentials (VsEPs) to linear acceleration pulses. Am. J. Otol. 20:238-243, 1999.

Pycock CJ, TARsY D, Marsden CD. Inhibition of turning behavior by clozapine in mice with unilateral destruction of dopaminergic nerve terminals. J. Pharm. Pharmacol. 27(6):445-447, 1975.

Rask-Andersen H, Erwall C, Steel KP, Friberg U. The endolymphatic sac in a mouse mutant with cochleo-saccular degeneration. Electrophysiological and ultrastructural correlations. Hear. Res. 26:177-190, 1987.

Ratty AK, Fitzgerald LW, Teitler M, Glick SD, Mullins JJ, Gross KW. Circling behavior exhibited by a transgenic insertional mutant. Mol. Brain Res. 8:355-358, 1990.

Rauch TM. The additive effects of two mutant genes on otolith formation in mice: an animal model to assess otolith function. J. Aud. Res. 19:259-265, 1979.

Reske-Kunz AB, Scheid MP, Boyse EA. Disproportion in T-cell subpopulations in immunodeficient mutant $\mathrm{hr} / \mathrm{hr}$ mice. J. Exp. Med. 149, 228-233, 1979.

Riley BB, Grunwald DJ. A mutation in zebrafish affecting a localized cellular function required for normal ear development. Dev. Biol. 179:427-435, 1996.

Riley BB, Zhu C, Janetopoulos C, Aufderheide KJ. A critical period of ear development controlled by distinct populations of ciliated cells in the zebrafish. Dev. Biol. 191:191-201, 1997.

RolfSEn RM, ERWAY LC. Trace metals and otolith defects in mocha mice. J. Hered. 75(3):159-162, 1984.

Ruben RJ. The history of the genetics of hearing impairment. Ann. N. Y. Acad. Sci. 630:6-15, 1991.

Ruben RJ, Van De Water TR, Steel KP. Genetics of Hearing Impairment. New York Academy of Sciences, New York, 1991.

Sidman RL, Kickie MM, ApPel SH. Mutant mice (quaking and jimpy) with deficient myelination in the central nervous system. Science 144:309-311, 1964.

Siemens J, Lillo C, Dumont RA, Reynolds A, Williams DS, Gillespie PG, Muller U. Cadherin 23 is a component of the tip link in hair-cell stereocilia. Nature 428(6986):950-955, 2004.

Sjostrom B, Anniko M. Morphologically specific vestibular hair cell degeneration in the jerker mouse mutant. Eur. Arch. Otorhinolaryngol. 247:51-55, 1990.

Sollner C, Rauch GJ, Siemens J, Geisler R, Schuster SC, Muller U, Nicolson T. Tubingen 2000 Screen Consortium. Mutations in cadherin 23 affect tip links in zebrafish sensory hair cells. Nature 428(6986):955-959, 2004.

Southard JL. Jackson circler, jc. Mouse News Lett. 42:30, 1970.

SteEL K. Hered. Deaf. Newslett. 4:5-22, 1990.

STEEL K. Similarities between mice and humans with hereditary deafness. Ann. N. Y. Acad. Sci. 630:68-79, 1991.

SteEl KP. Inherited hearing defects in mice. Annu. Rev. Genet. 29:675-701, 1995.
Steel KP, Bock GR. Hereditary inner-ear abnormalities in animals. Relationships with human abnormalities. Arch. Otolaryngol. 109:22-29, 1983.

Steel KP, Brown SD. Genes and deafness. Trends Genet. 10:428435, 1994.

Steel KP, BRown SD. Genetics of deafness. Curr. Opin. Neurobiol. 6:520-525, 1996.

Steel KP, Erven A, Kiernan AE. Mice as models for human hereditary deafness. In: Keats BYB, Popper AN, Fay RR (eds) Genetics and Auditory Disorders. Springer-Verlag, New York, pp. 247-296, 2002.

Street VA, McKee Johnson JW, Fonseca RC, Tempel BL, NobenTrauth K. Mutations in a plasma membrane $\mathrm{Ca}^{2+}$-ATPase gene cause deafness in deafwaddler mice. Nat. Genet. 19:390394, 1998

Thomas KR, Musci TS, Neumann PE, Capecchi MR. Swaying is a mutant allele of the proto-oncogene Wnt-1. Cell 67(5):969-976, 1991.

Toyoshi T, Ukai M, Kameyama T. Intrastriatal injection of opioid agonists inhibits apomorphine-induced behavior in 6-hydroxydopamine-treated mice. Eur. J. Pharmacol. 294(2-3):637-643, 1995.

Trune DR, Lim DJ. The behavior and vestibular nuclear morphology of otoconia-deficient pallid mutant mice. J. Neurogenet. 1:53-69, 1983a.

Trune DR, Lim DJ. A morphometric study of the pallid mutant mouse inner ear. Am. J. Otolaryngol. 4:261-272, 1983b.

Van Alphen AM, Stahl J, Koekkoek S, de Zeeuw CI. (2001) The dynamic characteristics of the mouse vestibulo-ocular and optokinetic response. Brain Res. 890:296-305, 2001.

Vetter De, Mann JR, Wangemann P, Liu J, McLaughlin KJ, Lesage F, Marcus DC, Lazdunski M, Heinemann SF, Barhanin J. Inner ear defects by null mutation of the isk gene. Neuron 17:1251-1264, 1996.

Watanabe H, Ikeda M, Watanabe K. Properties of rotational behavior produced by methylxanthine derivatives in mice with unilateral striatal 6-hydroxydopamine induced lesions. J. Pharmacobiodyn. 4(4):301-307, 1981.

Webster DB, Sobin A, Anniko M. Incomplete maturation of brainstem auditory nuclei in genetically induced early postnatal cochlear degeneration. Acta Otolaryngol. 101:429-438, 1986.

Weil D, El-Amraoui A, Masmoudi S, Mustapha M, Kikkawa Y, Laine S, Delmaghani S, Adato A, Nadifi S, Zina ZB, Hamel C, Gal A, Ayadi H, Yonekawa H, Petit C. Usher syndrome type IG (USH1G) is caused by mutations in the gene encoding SANS, a protein that associates with the USH1C protein, harmonin. Hum. Mol. Genet. 12:463-471, 2003.

WeIsLeder P, PARK TJ. Belgian Waterslager canaries are afflicted by Scheibe's-like dysplasia. Hear. Res. 80:64-70, 1994.

Weisleder P, Lu Y, Park TJ. Anatomical basis of a congenital hearing impairment: basilar papilla dysplasia in the Belgian Walterslager canary. J. Comp. Neurol. 369:292-301, 1996.

Wenngren BI, Anniko M. Vestibular hair cell pathology in the dancer mouse mutant. Acta Otolaryngol. 107:182-190, 1989.

Whitfield TT, Granato M, van Eeden FJ, Schach U, Brand M, Furutani-Seiki M, Haffter P, Hammerschmidt M, Heisenberg CP, Jiang YJ, Kane DA, Kelsh RN, Mullins MC, Odenthal J, Nusslein-Volhard C. Mutations affecting development of the zebrafish inner ear and lateral line. Development 123:241-254, 1996.

Yerkes RM. The Dancing Mouse: A Study in Animal Behavior. The Animals Behavior Series 1. Macmillan, New York, 1907.

Zheng QY, Johnson KR, ERwaY LC. Assessment of hearing in 80 inbred strains of mice by ABR threshold analysis. Hear. Res. 130:94-107, 1999.

Zuo J, Dejager PL, Takahashi KA, Jiang W, Linden DJ, Heintz N. Neurodegeneration in Lurcher mice caused by mutation in delta2 glutamate receptor gene. Nature 388:769-773, 1997. 